\title{
RISKY ENERGY ASPECTS - IDENTIFICATION, EVALUATION, ACCEPTABILITY ASSESSMENT AND IMPROVEMENT AIMS
}

\author{
doi: 10.2478/cqpi-2019-0018 \\ Date of submission of the article to the Editor: 03/04/2019 \\ Date of acceptance of the article by the Editor: 15/05/2019
}

Tatiana Karkoszka - orcid id: 0000-0002-7853-3654

Silesian University of Technology Poland

\begin{abstract}
The increasing worldwide energy consumption, especially in the industry range, forces the companies to search for the solutions, which - being written into sustainable development philosophy - would allow for reducing the level of the energy consumption of the realised processes and lowering the costs of their functioning. Those activities can be undertaken in the systemic way, very often based on the implementation of the energy management system, they can also have the character of technical or technological modernisation. Fundament of the decision concerning the manner of the minimisation of energy consumption should always be the energy risk management covering: its identification, evaluation and acceptability assessment. The studies proposed the principles for defining the significant energy aspects by the full identification of all the present aspects and next the development of unified methodology of their assessment, allowing for appointing the key aspects. The starting point constitutes the energy risk ratio, which takes into consideration the following criteria: probability of the occurrence, significance of the occurrence, ability to monitor, incompatibility with legal requirements, and the interest and attention of the stakeholders. Flexibility of the applied method enables complex application in every organisation - independently of its size and sort of the realised processes which wants to manage the risky energy aspects.
\end{abstract}

Keywords: environmental management, energy aspects and risk, risk management, risk ratio

\section{INTRODUCTION}

According to the Annual Energy Outlook 2019 - reflecting the "most likely" trajectory of the world's energy system - the industrial consumption of the energy coming from all of the sources will have grown up approximately by 50\% till the year 2050 (Energy Outlook, 2019). It creates the increased pressure on the problem of the energy consumption. The companies are searching for the organisational and technological solutions, which would enable to reduce the level of the energy consumption of the realised processes, which would result in lowering the costs of their functioning. Several approaches of optimisation of energy usage have been identified (Goldberg et al., 2011; Greening et al., 2000; Mori et al., 2011). 
The aims concerning the energy efficiency and limiting the energy consumption are realised in the companies in the most effective way if the steps undertaken are of the systemic character. Such a system of energy management can have an individual character; however, it may also be the reflection of the normalised requirements described in the ISO 50001 standard (Giacon and Mancò, 2012; Gómez et al., 2014). The structure of the standard is based on the rules of HLS structure, which enables the norm's integration with the requirements of the other standards, especially ISO 14001 one and requires "risk based approach". Identification of risks allows for such a processes planning, which assures the compliance with energy targets. Assessment of the risks, in connection with performance indicators and energy overview, should be treated as a starting point for operational actions (ISO 5001, 2018; ISO/IEC, 2019). Indicators can be for example: direct and indirect energy consumption, energy saved due to conservation and efficiency improvements, initiatives to provide energyefficient or renewable energy based products and services, initiatives to reduce indirect energy consumption and reductions achieved (Duglio, 2011). Indicators form a bases for assessment of the risk.

Risk assessment should always include: identification of the risk including its sources, risk analysis allowing for measuring its values and their comparison with acceptability criterion (ISO 31000, 2018; Karkoszka, 2013).

The methodologies for the selection of indicators and risk assessment are not defined. Organisation should work out the specific methods and tools and include it in the energy system (Duglio, 2011; Bolado et al., 2012).

The energy overview enables to determine these areas of organisation's activity which are connected with the meaningful energy consumption and in which there is a possibility to limit it. In reference to the meaningful energy aspects, the organisation defines the aims, tasks and the plans, which may improve the energy result in the range of the areas with the significant energy loss within the company (ISO 5001, 2018; Eccleston et al., 2012; May G. et al, 2015).

The actions connected with refining the energy cannot have the character of the temporary solutions, which would ensure just a momentary energy saving. The actions mentioned should be of the good engineering practice and may require application of the technological solutions, which are enforced by the expiring life cycle of the particular devices or the whole installation (Słupik, 2012).

50001 requirements are of the universal character and the organisation, which implemented the system, has to work out and apply the appropriate methods, tools and rules directed to requirements' fulfilment. Such a specific methodology is risk management covering: its identification, evaluation as well as - if it is indispensable its minimising by undertaking the organisational or modernising activities (Karkoszka and Soković, 2014; Karkoszka, 2016).

\section{METHODOLOGY OF ENERGY RISK MANAGEMENT}

In the company being the subject matter of the analysis the most frequently occurred aspects connected with the energy consumption or the energy resources represent the environmental aspects of the meaningful character. Therefore it is crucial to manage these aspects in the integrated way basing on the 14001 requirements and supplemented with the guidelines of ISO 50001 standard, including the developed by the organisation method of identification and assessment of the energy and environmental aspects and refraining from them energy and environmental risk. 
Description of each of the energy aspects covers the following: source of the aspect, level values or required values concerning the energy aspect together with the adequate issued permissions and decisions or identified legal requirements.

Evaluation of the identified energy and environmental aspects as well as the meaning of the significant aspects is realised in accordance with the developed methodology.

The report, being the effect of the energy check-up, describes the energy efficiency connected with the significant energy aspects. The information included in the report enable the assessment of the further use and consumption of the energy, which in turn constitutes the base for the assessment of the energy baseline for the next period of time together with taking into account the possibilities of identification of energy efficiency improvement.

\subsection{Method of assessment of the energy aspects}

The base for defining the significant environmental aspects, as well as the energy one, is full identification of all the present aspects and next the application of the unified methodology of their assessment, allowing for appointing the key aspects.

The developed methodology requires the calculation of the risk connected with occurrence of the energy aspect and its impacts.

Risk has been defined as the probability of the occurrence of energy aspect and the consequences connected with it. And what is more, one has described its own measures considering energy aspects and influencing their effects. Therefore, in the analysed circumstances while assessing each of the energy aspect, one should take into consideration the following criteria: probability of the occurrence $(P)$, significance of the occurrence $(S)$, ability to monitor $(M)$, incompatibility with legal requirements $(\mathrm{L})$, and finally the interest and attention of the stakeholders $(A)$.

To each of the criterion the proper amount of points, scaled from 1 to 5 (where 5 means the most unfavourable situation) is assigned. Those points depend on the worked out descriptive instructions being the element of the risk methodology. They include the concrete conditions which have to be fulfilled to specify the particular amount of points.

For each of the criterion the amount of points is multiplied by the factor of importance for the particular criterion (I) defined once by the group of the experts of energy analysis. The outcome of the assessment of each aspect is reflected by the sum of the products of the amount of points assigned to the criterion and its importance. The factor of risk for each of the energy aspect can be expressed based on the following formula:

$$
R=P \cdot I P+S \cdot I S+M \cdot I M+L \cdot I L+I \cdot I A
$$

$\mathrm{R}$ - risk ratio for energy aspect,

$\mathrm{P}$ - probability of the occurrence of energy aspect,

$S$ - significance of the occurrence of energy aspect,

$\mathrm{M}$ - ability to monitor energy aspect,

$L$ - incompatibility with legal requirements,

A - interest and attention to the influence of the energy aspect by the internal and external stakeholders,

IP, IS, IM, IL, IA - importance of the particular criteria. 
Probability of the occurrence of energy aspect defines a frequency on with the energy aspect are contaminants of the realised processes. Significance of the occurrence of energy aspects means value of the wear of energy connected with energy aspect. Ability to monitor the energy aspects is characterised by effectiveness of the used methods and tools of energy measurements. The incompatibilities with legal regulations reflect the unfulfilled legal and other requirements. The unfulfilled requirements definitely qualify the particular aspect as a meaningful and significant one. The factors connected with the interested parties are as the following: requirements of the clients, strategy and policy of the company, reported complaints by the neighbours and the workers. The guidelines for assessment of the energy aspects have been compared in the Table 1.

Table 1

Specification of the guidelines for energy aspects' assessment

\begin{tabular}{|c|c|c|c|}
\hline \multirow{2}{*}{ Criteria } & \multicolumn{2}{|c|}{ Values } & \multirow{2}{*}{$\begin{array}{l}\text { Importance } \\
\text { factor }\end{array}$} \\
\hline & 1 & 5 & \\
\hline $\begin{array}{c}\text { Significance } \\
\text { (S) }\end{array}$ & $\begin{array}{c}\text { Small value of wear } \\
\text { of energy }\end{array}$ & $\begin{array}{c}\text { High value of wear } \\
\text { of energy }\end{array}$ & 4 \\
\hline $\begin{array}{l}\text { Probability } \\
\text { of the occurrence } \\
(\mathrm{P})\end{array}$ & $\begin{array}{c}\text { Small frequency } \\
\text { of occurring the energy } \\
\text { aspect }\end{array}$ & $\begin{array}{c}\text { High frequency } \\
\text { of occurring the energy } \\
\text { aspect }\end{array}$ & 4 \\
\hline Ability to monitor (M) & High ability to measure & Small ability to measure & 3 \\
\hline $\begin{array}{c}\text { Incompatibilities with } \\
\text { legal regulations } \\
(\mathrm{L})\end{array}$ & $\begin{array}{l}\text { Probability of fulfilling } \\
\text { all of the legal } \\
\text { requirements }\end{array}$ & $\begin{array}{l}\text { Probability of not fulfilling } \\
\text { the legal requirements }\end{array}$ & 5 \\
\hline $\begin{array}{l}\text { Interested parties } \\
\text { (A) }\end{array}$ & $\begin{array}{l}\text { Energy aspect does not } \\
\text { cause any interest and } \\
\text { concern from the side } \\
\text { of the involved parties }\end{array}$ & $\begin{array}{l}\text { Energy aspect causes } \\
\text { very high interest and } \\
\text { concern from the side } \\
\text { of the stakeholders }\end{array}$ & 1 \\
\hline
\end{tabular}

The assessment of the energy aspects enables preparation of the register of the meaningful energy aspects covering the following: name of the significant energy aspect and its characteristics as well as the point of occurrence, outcome of the assessment and the energy performance index. There is no stiff threshold of risk acceptability. According to the assumed - as low as reasonably practicable - rule, the organisation, specifying ranges of risk acceptability, decides by itself which values of the risk factor reflect the significant aspects and which aspects are of no significance for the company. One should keep in mind and consider the fact that together with the technological and organisational development the level of the risk factor value for the significant aspect will be undergoing the lowering process.

On the base of the risk factor values the organisation undertakes the decisions concerning the ways of undertaking the particular risk.

\section{RESULTS}

The organisation, in which one has taken advantage of the proposed methodology of energy aspects management, realises the diagnostic and renovation actions in the industry. The task is to maintain the machines work - ensuring the availability of the manufacture devices, preventing the devices' failures and the current, middle size and the general overhaul. 
The organisation is equipped with the technical devices, and especially with the following: controlling-measuring, machines and tools for machining, welding devices and the machinery used for transportation of personnel, devices and the spare parts. Based on the developed procedure one has carried out in the analysed organisation the identification as well as the evaluation of the environmental aspects. The results for assessment of the energy aspects - being the specific group of the environmental aspects - have been compared in the Table 2 .

Table 2

Comparison of the chosen outcomes of the energy aspects assessment

\begin{tabular}{|c|c|c|c|c|c|c|c|}
\hline \multirow{2}{*}{$\begin{array}{l}\text { Source } \\
\text { of the } \\
\text { energy } \\
\text { aspect }\end{array}$} & \multirow{2}{*}{$\begin{array}{l}\text { Energy } \\
\text { aspect }\end{array}$} & \multicolumn{6}{|c|}{ Assessment of the energy aspects - criteria } \\
\hline & & $\begin{array}{c}\mathbf{P} \\
\mathrm{IP}=4\end{array}$ & $\stackrel{S}{S}=4$ & $\stackrel{M}{M}=3$ & $\mathrm{IL}=5$ & $\stackrel{A}{A}=1$ & $\mathbf{R}$ \\
\hline $\begin{array}{l}\text { Machining } \\
\text { devices }\end{array}$ & $\begin{array}{l}\text { Consumption } \\
\text { of electric } \\
\text { energy in } \\
\text { machining } \\
\text { devices } \\
\end{array}$ & $3 \cdot 4=12$ & $4 \cdot 4=16$ & $3 \cdot 3=9$ & $1 \cdot 5=5$ & $3 \cdot 1=3$ & 45 \\
\hline $\begin{array}{l}\text { Welding } \\
\text { processes }\end{array}$ & $\begin{array}{l}\text { Consumption } \\
\text { of electric } \\
\text { energy in } \\
\text { welding } \\
\text { processes }\end{array}$ & $3 \cdot 4=12$ & $3 \cdot 4=12$ & $3 \cdot 3=9$ & $1 \cdot 5=5$ & $2 \cdot 1=2$ & 40 \\
\hline Transportation & $\begin{array}{c}\text { Consumption } \\
\text { of fuel }\end{array}$ & $2 \cdot 4=8$ & $3 \cdot 3=9$ & $1 \cdot 3=3$ & $1 \cdot 5=5$ & $1 \cdot 1=1$ & 26 \\
\hline Heat radiators & $\begin{array}{c}\text { Consumption } \\
\text { of heat energy } \\
\text { for heating }\end{array}$ & $2 \cdot 4=8$ & $3 \cdot 4=12$ & $1 \cdot 3=3$ & $1 \cdot 5=5$ & $1 \cdot 1=1$ & 29 \\
\hline $\begin{array}{l}\text { Sources of } \\
\text { lightening }\end{array}$ & $\begin{array}{l}\text { Consumption } \\
\text { of electric } \\
\text { energy } \\
\text { for lighting }\end{array}$ & $4 \cdot 4=16$ & $2 \cdot 4=8$ & $1 \cdot 3=3$ & $1 \cdot 5=5$ & $1 \cdot 1=1$ & 33 \\
\hline Compressors & $\begin{array}{l}\text { Consumption } \\
\text { of electric } \\
\text { energy } \\
\text { in compressors }\end{array}$ & $1 \cdot 4=4$ & $3 \cdot 4=12$ & $3 \cdot 3=9$ & $1 \cdot 5=5$ & $4 \cdot 1=4$ & 34 \\
\hline
\end{tabular}

As the meaningful and significant aspects among the energy ones, one has pointed the aspects for which the value of the risk ratio amounted 30 and more points. As the meaningful aspects it has also been indicated creating the same energy influence (like consumption of heat and electric energy for heating) for which the sum of the value of the risk ratio amounted to more than 45 points.

The range has included: heating energy consumption and the electric energy: in the processes of machining and welding as well as for heating and lighting.

Based on the results of the assessment of the energy aspects one has proposed application of the actions aiming at minimising and limiting the energy risk, which are in accordance with the Table 3. 
Table 3

Specification of the chosen improvement activities

\begin{tabular}{|c|c|c|c|c|}
\hline $\begin{array}{l}\text { Energy } \\
\text { aspect }\end{array}$ & $\mathbf{R}$ & Strategic aim & Operational aim & Task \\
\hline $\begin{array}{l}\text { Consumption } \\
\text { of electric } \\
\text { energy in } \\
\text { machining } \\
\text { devices }\end{array}$ & 45 & $\begin{array}{l}\text { Optimisation of } \\
\text { consumption } \\
\text { of electric energy } \\
\text { in machining } \\
\text { devices }\end{array}$ & $\begin{array}{l}\text { Decrease of the } \\
\text { energy performance } \\
\text { indicator by } 8 \% \\
\text { in relation } \\
\text { to the reference level }\end{array}$ & $\begin{array}{l}\text { Operational procedures } \\
\text { for machines, monthly } \\
\text { and biannual employees' } \\
\text { training in the range of } \\
\text { rationalisation of electric } \\
\text { energy consumption }\end{array}$ \\
\hline $\begin{array}{c}\text { Consumption } \\
\text { of electric } \\
\text { energy for } \\
\text { lighting }\end{array}$ & 33 & $\begin{array}{l}\text { Reduction of } \\
\text { consumption } \\
\text { of electric energy } \\
\text { for lighting } \\
\text { in production } \\
\text { buildings }\end{array}$ & $\begin{array}{l}\text { Decrease of the } \\
\text { energy performance } \\
\text { indicator by } 36 \% \\
\text { in relation } \\
\text { to the reference level }\end{array}$ & $\begin{array}{l}\text { Monitoring of consumption } \\
\text { of electric energy } \\
\text { for lighting, changing } \\
\text { the traditional light bulbs } \\
\text { for low-energy ones, } \\
\text { installation of dust } \\
\text { detectors }\end{array}$ \\
\hline $\begin{array}{l}\text { Consumption } \\
\text { of electric } \\
\text { energy for } \\
\text { heating }\end{array}$ & 29 & $\begin{array}{l}\text { Optimisation of } \\
\text { consumption } \\
\text { of electric energy } \\
\text { for heating, } \\
\text { improvement of } \\
\text { employees' heat } \\
\text { comfort in } \\
\text { production } \\
\text { buildings }\end{array}$ & $\begin{array}{c}\text { Decrease of the } \\
\text { energy performance } \\
\text { indicator by } 30 \% \text { in } \\
\text { relation to the } \\
\text { reference level, } \\
\text { maintenance } \\
\text { of the temperature } \\
\text { on minimal level } \\
\text { of } 16^{\circ} \mathrm{C} \text { in the heating } \\
\text { season }\end{array}$ & $\begin{array}{l}\text { Thermal insulation of } \\
\text { production buildings, } \\
\text { monthly employees' } \\
\text { training in the range of } \\
\text { rationalisation of electric } \\
\text { energy consumption }\end{array}$ \\
\hline
\end{tabular}

They were of the both organisational and modernising character and particularly they covered: operating procedures for machines, monthly and biannual employees' training in the range of rationalisation of electric energy consumption and thermal insulation of production buildings.

\section{CONCLUSIONS}

The reduction of the embodied energy of the processes realised in organisations, being unequivocal with the minimisation of the functioning costs, determines the strategy aims of many organisations. Therefore, companies undertake activities both of: the system character, very often based on the implementation of the energy management system and of the character of technical or technological modernisation. The realised research is the confirmation that organisations manage the energy aspects in very different ways. Very often they directly identify the energy aspect with energy risk and direct the activities towards risk minimisation. At the same time organisations apply different methods of energy risk assessment.

For the analysed organisation one has prepared the methodology of energy risk management - being formally qualified as environmental risk. The methodology includes: identification of the energy aspect, assessment of the energy risk based on the application of the risk ratio, undertaking the organisational and technological improvement activities. The used energy risk ratio takes into account: probability and significance of the occurrence of energy aspect, ability to monitor the energy aspects, fulfilment of legal and other requirements as well as interest and concern from the side of the stakeholders. Energy risk assessment creates a basis for the 
determination in the process threats of the significant character crucial in the aspect of the fulfilling the energy requirements.

In the organisation, where the energy risk assessment method has been tested, as the most important energy aspects, one has qualified: consumption of electric energy in machining devices, welding processes and compressors, consumption of electric energy for lighting and consumption of heat and electric energy for heating.

The highest degree of the risk ratio for the significant aspects has been calculated as 45 for consumption of electric energy in machining devices, 40 for consumption of electric energy in welding processes, 34 for consumption of electric energy by compressors, 33 for consumption of electric energy for lighting and total 58 for consumption of heat and electric energy for heating.

The undertaken actions aiming at limiting the energy consumption and the energy risk covered organisational and technological solutions like: operating procedures for machines, employees' training in the range of rationalisation of electric energy consumption as well as thermal insulation of production buildings and exchanging the traditional light bulbs into low-energy light ones, connected with the installation of dust detectors.

The research has confirmed the meaning of the individual choice of the applied methods of energy risk management, also the methods of its assessment. The analysis has also showed how important for the successive reduction of the embodied energy it is to apply the long-term solutions. Such a plan can be carried out both as: technical and technological modernisation, application of the control and measurement equipment and the deliberate involvement of all employees in the process of the improvement of energy effectiveness of organisation.

Value of the conducted research is being constituted by the methodology of energy risk management, included in the energy management system and containing procedure of managing the energy aspects, also the method of assessment of energy aspects' risk. Findings of analysis are as follows: energy management can be realised as the energy risk management resulting in energy risk minimisation or elimination by the technical and technological modernisation or organisational improvement. Practical implication can be applied in case of any organisation which wants to manage the risky energy aspects.

\section{REFERENCES}

Bolado R., Gracceva F., Zeniewski P., Zastera P., Vanhoorn L., Mengolini A., 2012. Best practices and methodological guidelines for conducting gas risk assessments, European Commission Joint Research Centre Institute for Energy and Transport.

Duglio S., 2011. Energy Management Systems: from EN 16001 to ISO 50001, Romanian Distribution Committee Magazine, 2, 18-21.

Eccleston Ch. H., March F., Cohen F., 2012. Inside Energy, Developing and managing an ISO 50001 energy management system, CRC Press, Boca Raton, 37-126.

Giacon E., Mancò S., 2012. Energy efficiency measurement in industrial processes, Energy, 38, 331-345.

Goldberg A., Reinaud J., Taylor R.P., 2011. Promotion Systems and Incentives for Adoption of Energy Management Systems in Industry, Institute for Industrial Productivity, www.ippnetwork.org. 
Gómez J.M., Sonnenschein M., Vogel U., Winter A., Rapp B., Giesen N. (Eds.), 2014. Information and communication technology for energy efficiency, BIS-Verlag, Oldenburg, 581-588.

Greening L.A., Greene D.L., Difiglio C., 2000. Energy efficiency and consumption the rebound effect - a survey, Energy Policy, 28, 389-401.

Karkoszka T., 2013. Risk management as an element of processes continuity assurance, Procedia engineering, 63, 873-877.

Karkoszka T., Soković M., 2014. Risk based on quality, environmental and occupational safety in heat treatment processes, Metalurgija, 53, 545-548.

Karkoszka T., 2016. Factors influencing the requirements fulfillment in the zinc coating processes, Metalurgija, 55, 765-768.

May G., Barletta I., Stahl B., Taisch, M., 2015. Energy management in production: $A$ novel method to develop key performance indicators for improving energy efficiency, Applied Energy, 149, 46-61.

Mori M., Fujishima M., Inamasu Y., Oda Y., 2011. A study on energy efficiency improvement for machine tools, CIRP Annals - Manufacturing Technology, 60, 145-148.

Słupik T., 2012. Good engineering practise in the process of technical and economic optimisation of devices, Proceedings of the 4th conference on Optimisation of the energy processes - good engineering practice in the power sector and in the industry, Poland.

ISO 14001, 2015. Environmental management systems - Requirements with guidance for use, ISO, Genève, Switzerland.

ISO 31000, 2018. Risk management - Guidelines, ISO, Genève, Switzerland.

ISO 50001, 2018. Energy management systems - Requirements with guidance for use, ISO, Genève, Switzerland.

ISO/IEC Directives, 2019. Part 1, Consolidated ISO supplement, Procedures specific to ISO, Appendix 2, ISO, Genève, Switzerland.

Annual Energy Outlook 2019 with projections to 2050, U.S. Energy Information Administration, www.eia.gov/aeo. 